\title{
TECHNICAL EVALUATION OF DRIVER ACTIONS \\ AT THE SIGNAL CONTROLLED CROSSROAD WHILE SIGNAL CHANGING FROM GREEN LIGHT TO STOPLIGHT
}

\section{Lubentsov A. V, Sviderskyi $O$. $O$.}

Due to the fact that currently on the vehicles drivers began increasingly to install video recorders, and external observation cameras on buildings and constructions are installed, then in carrying out forensic autotechnical examination, technical analysis of traffic situations with taking into account presented video recordings becomes to be a necessity. In studying various road traffic situations at the signal controlled crossroads, expert should have some initial data, namely, the speed of vehicles before a traffic accident, on which traffic signal they were moving at the time of running to the crossroads, at what distance from the near border crossroad the vehicle was at the time of activation of a yellow traffic light, i. e. the input data, without which it is impossible to carry out a full technical analysis of traffic situations and perform calculations. The paper shows an example of the road transport situation which was registered by a camera of external observation. In the presence of the video recording of the road traffic accidents mechanism and registration of traffic lights objects on this video recording, vehicle or a pedestrian, to establish an expert way on which traffic signal the vehicle moved out it is possible by using cyclogram their works. If video recording of the traffic accident mechanism it is not registered traffic lights, then it is impossible by means of an expert way to determine on which traffic signal the collision of vehicles occurred, and therefore further technical analysis of the driver's actions should be carried out on the version of each of them.

Keywords: traffic accident, traffic signals, crossroads, vehicle, video recording.

B. $\boldsymbol{C}$. Ольхов, старший науковий співробітник Харківського НДІСЕ,

B. O. Степко, судовий експерт Харківського НДІСЕ,

O. М. Панасенко, судовий експерт Харківського НДІСЕ

\section{ЕКСПЕРТНЕ ДОСЛІДЖЕННЯ ДОРОЖНЬО- ТРАНСПОРТНИХ ПОДІЙ, ПОВ'ЯЗАНИХ ІЗ НАЇЗДОМ НА ПІШОХОДІВ ПРИ НЕНАЛЕЖНОМУ ТЕХНІЧНОМУ ОБЛАШТУВАННІ ПШШОХІДНОГО ПЕРЕХОДУ}

Розглянуто питання, які виникають у експертів під час проведення судових автотехнічних експертиз (експертних досліджень) при наїзді на пімоходів, які перетинали проїзну частину по наземному нерегульованому пішохідном переходi.

Ключові слова: дорожньо-транспортна пригода, наземний нерегульований пімохідний перехід, пішохід, наӥзд на пішохода.

Експертна практика проведення судових автотехнічних експертиз показала, що майже у 30 \% усіх призначених судово-слідчими органами екс-

(c) Ольхов В. С, Степко В. О., Панасенко О. М., 2016 
пертиз дослідженню підлягають наїзди транспортних засобів на пішоходів. При цьому близько 50 \% експертних проваджень, що стосуються наїздів на пішоходів транспортними засобами, це наїзди транспортних засобів на пішоходів, які перетинали проїзну частину по нерегульованому пішохідному переході.

На сьогодні в експертній практиці проведення автотехнічних досліджень, що стосується наїздів на пішоходів, які перетинали проїзну частину по наземному нерегульованому пішохідному переході, не існує єдиної методики проведення подібних досліджень. Методика дослідження наїзду на пішоходів транспортними засобами не розділяє дослідження за критерієм, чи був здійснений наїзд на пішохода на нерегульованому (регульованому) пішохідному переході. Єдина відмінність при дослідженнях, коли стався наїзд на пішохода на наземному нерегульованому пішохідному переході, це застосування при розрахунках зупинного шляху ситуаційного часу реакції водія на небезпеку $-0,8 \mathrm{c}^{1}$.

Технічна оцінка дій водія, який допустив наїзд на наземному нерегульованому пішохідному переході, за умови відсутності інших транспортних засобів, що рухаються в попутному напрямку та знижують швидкість перед нерегульованим пішохідним переходом, пов'язана з оцінюванням відповідності дій водія транспортного засобу вимогам пп. 12.3 та 18.1 Правил дорожнього руху України (ПДР України). Тобто під час проведення досліджень експерт установлює, чи міг водій із моменту виникнення небезпеки, застосувавши заходи для екстреного гальмування, надати дорогу пішоходу. При цьому момент виникнення небезпеки для руху водіям експерти приймають, як правило, момент виходу пішохода на пішохідний перехід.

При проведенні технічного оцінювання дій водія, майже завжди, не оцінюється належність технічного облаштування наземних нерегульованих пішохідних переходів технічними засобами організації дорожнього руху.

У зв’язку з неналежним фінансуванням організацій, які відповідають за розміщення, ремонт і своєчасне оновлення технічних засобів організації дорожнього руху, а саме дорожніх знаків, дорожньої розмітки та інше, техніко-експлуатаційний стан засобів організації дорожнього руху має подекуди знос до 100 \%. Ця обставина призводе до того, що учасники дорожнього руху не достатньо інформовані або несвоєчасно інформовані про організацію дорожнього руху в місці розташування наземного нерегульованого переходу. Тобто пішохід, який підходить до пішохідного переходу з метою перетину проїзної частини, бачить нанесену дорожню розмітку на проїзній частині, навіть якщо ії експлуатаційний стан уже не відповідає нормативним вимогам, тому що він знаходиться в безпосередній близькості до неї. Водій транспортного засобу до моменту виходу пішохода на наземний пішохідний перехід знаходиться на деякому віддаленні від розташування дорожньої розмітки, тому при неналежному експлуатаційному стані дорожньої роз-

${ }^{1}$ Див.: Суворов Ю. Б. Применение дифференцированных значений времени реакции водителя в экспертной практике / Ю. В. Суворов ; под ред. В. А. Иларионова, А. К. Педенчука, В. Н. Янина. — М. : ВНИИСЭ, 1987. — 20 с. 
мітки, що позначає наземний нерегульований пішохідний перехід, водій позбавлений можливості завчасно визначити, що попереду нього наявний наземний нерегульований пішохідний перехід, а відповідно й завчасно не має можливості провести аналіз можливих дій пішохода, який наближається до проїзної частини.

Це ж стосується наїздів на пішоходів у темний час доби за відсутності зовнішнього освітлення на наземних нерегульованих пішохідних переходах. Тобто при наближенні до переходу пішохід має можливість бачити транспортний засіб на значній відстані від пішохідного переходу, оскільки транспортні засоби в темний час доби рухаються із включеним зовнішнім освітленням. Оцінивши відстань і переконавшись у безпеці, він починає перехід проїзної частини по наземному нерегульованому пішохідному переході, як то передбачено вимогами пп. 4.7 та 4.14 ПДР України. Водій, наближаючись до наземного пішохідного переходу, на якому відсутнє зовнішнє освітлення, може побачити пішохода в останню мить, безпосередньо перед наїздом. Водій у цій дорожньо-транспортній ситуації також позбавлений можливості завчасно визначити: по-перше, що попереду нього наявний наземний нерегульований пішохідний перехід, а по-друге, виявити вчасно, що по ньому рухається пішохід. При цьому вимогами п. 4.4 ПДР України в темну пору доби та в умовах недостатньої видимості пішоходи, які рухаються проїзною частиною чи узбіччям, повинні якимось чином визначити себе.

На сьогодні в експертній практиці під час технічного аналізу дій водіїв транспортних засобів, які допустили наїзд на пішохода на наземному нерегульованому пішохідному переході, що не були належним чином позначені, відсутній єдиний підхід до технічного оцінювання дій водіїв у разі вчинення дорожньо-транспортної пригоди (ДТП). Зазначена проблема не вирішена належним чином як у теоретичному, так і практичному аспектах. Це створює умови для різного підходу до технічного оцінювання дій водіїв транспортних засобів при аналізуванні обставин ДТП.

Установлення неналежності технічного облаштування наземних пішохідних переходів належить до експертної спеціальність 10.16 «Дорожньотехнічні дослідження».

Узагалі в довідково-нормативній літературі з питань теорії та практики судової автотехнічної та дорожньо-технічної експертиз відсутні роботи, які б стосувалися проблематики такого роду, оскільки для цього необхідно проводити комплексні дорожньо-технічні та автотехнічні дослідження з метою встановлення відповідності обладнання, розташування, експлуатаційного стану технічних засобів та інженерного облаштування в зонах дії нерегульованих пішохідних переходів.

Розглянемо приклад наїзду на пішохода на нерегульованому пішохідному переході, який не мав належного технічного облаштування.

До Харківського НДІСЕ для проведення комплексної судової автотехнічної та дорожньо-технічної експертизи надійшли матеріали кримінального провадження стосовно факту наїзду автомобіля «Рено» на пішохода. У ході вивчення матеріалів цього кримінального провадження експертами було встановлено: наїзд на пішохода мав місце в темну пору доби в населе- 
ному пункті, який позначений дорожнім знаком 5.47 «Початок населеного пункту» (Найменування і початок забудови населеного пункту, у якому на даній дорозі не діють вимоги ПДР України, що визначають порядок руху в населених пунктах). Пішохід до наїзду рухався зліва направо стосовно напрямку руху автомобіля «Рено». 3 моменту виходу на пішохідний перехід до моменту наїзду пішохід подолав відстань близько 18 м. Видимість пішохода 3 робочого місця водія автомобіля «Рено» становила 20,8 м, а швидкість його - 100 км/год. Автомобільна дорога, де сталася ДТП, належить до I-ї технічної категорії.

На вирішення експертизи були поставлені питання: чи забезпечувала організація дорожнього руху на дослідній ділянці дороги безпеку дорожнього руху та чи були невідповідності дорожніх умов вимогам нормативних документів у причинному зв'язку з подією ДТП.

При аналізуванні наданих на дослідження матеріалів справи було встановлено, що в місці ДТП було відсутнє зовнішнє освітлення, як указано у вимогах підп. 4.5.6 ДБН В.2.3-4:2007¹, оскільки воно просто не було передбачене при проведенні капітального ремонту ділянки дороги, на якій мало місце ДТП.

Оскільки зовнішнє освітлення не було передбачене, то в цьому разі перед наземним пішохідним переходом необхідно було для забезпечення безпеки дорожнього руху додатково встановити попереджувальний знак 1.32 «Пішохідний перехід» і ввести локальне обмеження швидкості руху перед пішохідним переходом, із ступінчастим обмеженням швидкості руху транспортних засобів із кроком не більш 20 км/год, до швидкості не менше 40 км/год. Тобто додатково встановити дорожні знаки 3.29 «Обмеження максимальної швидкості».

Оскільки на наземному пішохідному переході автомобільної дороги I-ї технічної категорії не було передбачене та було відсутнє зовнішнє освітлення, не були встановлені додаткові засоби організації дорожнього руху, що не давало змоги учасникам дорожнього руху завчасно вжити заходів для безпечного проїзду наземного пішохідного переходу, не створюючи небезпеки пішоходам, які перетинають проїзну частину, тому був зроблений висновок, що на ділянці дороги, де мав місце наїзд на пішохода, не була забезпечена безпека дорожнього руху. Тому невідповідність загальним вимогам розділу 3 ДСТУ $3587-97^{2}$, підп. 10.3.1, 10.3.2, 10.3.33, 10.5.25 ДСТУ 4100-20023 та підп. 4.5.6 ДБН В.2.3-4:2007 з технічної точки зору знаходилися в причинному зв'язку з виникненням даної дорожньо-транспортної пригоди.

1 Див.: Споруди транспорту. Автомобільні дороги. Ч. І. Проектування. Ч. II. Будівництво : ДБН В.2.3-4:2007 [Електронний ресурс] // Інформаційна довідникова система «Будстандарт». - Режим доступу : http://budstandart.com/ версія 3.1.0.

2 Див.: Автомобільні дороги, вулиці та залізничні переїзди. Безпека дорожнього руху. Вимоги до експлуатаційного стану : ДСТУ 3587-97 [Електронний ресурс] // Інформаційна довідникова система «Будстандарт».

Див.: Знаки дорожні. Загальні технічні умови. Правила застосування : ДСТУ 4100-2002 [Електронний ресурс] // Інформаційна довідникова система «Будстандарт». 
Слідчим у постанові про призначення судової дорожньо-технічної експертизи не були поставлені питання стосовно технічної оцінки дій водія автомобіля «Рено» в цій дорожньо-транспортній ситуації. Однак при вивченні матеріалів кримінального провадження були встановлені обставини, які мають значення для прийняття об'єктивного рішення у справі. Тому відповідно до вимог статей 69, 102 КПК України та п. 2.1 Інструкції про призначення та проведення судових експертиз та експертних досліджень експертами у висновку були вказані такі обставини.

При проведенні слідчого експерименту було встановлено, що водій автомобіля «Рено» не мав технічної можливості (у зв'язку зі ступенем освітлення пішохідного переходу) бачити пішохода (пішоходів) на всьому шляху його руху через проїзну частину по нерегульованому пішохідному переходу. Тому у висновку було вказано, що й дії водія автомобіля «Рено» також знаходяться в причинному зв'язку з виникненням цієї ДТП, а саме невідповідність його дій вимогам п. 18.1 ПДР України. Оскільки саме наявність обмеженої видимості зони нерегульованого пішохідного переходу слугує головною інформаційною ознакою того, що на пішохідному переході, видимість на якому була обмежена, може перебувати пішохід, якому водій автомобіля «Рено» повинен дати переважне право на перетинання автомобільної дороги. Тому водію автомобіля «Рено», наближаючись до пішохідного переходу, видимість дорожніх знаків і розмітки якого була завчасною, необхідно також заздалегідь обрати безпечний швидкісний режим (швидкість руху), щоб мати технічну можливість своєчасним і не екстреним зниженням швидкості дати дорогу пішоходові, який може з'явитися в зоні обмеженої видимості пішохідного переходу та має переважне право на рух.

На сьогодні експертами Харківського НДІСЕ була виконана перша спроба визначити єдиний підхід до технічної оцінки дій водіїв при ДТП, пов'язаних з наїздом на пішоходів при неналежному технічному облаштуванні наземного нерегульованого пішохідного переходу, а саме була розроблена методика «Експертне дослідження дій водія під час ДТП при неналежному облаштуванні технічними засобами пішохідних переходів та перехресть». У цій методиці колективом авторів був запропонований алгоритм експертного дослідження з оцінювання дій водіїв і визначення впливу неналежного обладнання, застосування, розташування, експлуатаційного стану технічних засобів та інженерного облаштування наземних нерегульованих перехресть на виникнення ДТП.

Підсумовуючи зазначене, уважаємо, що при проведенні досліджень наїздів транспортних засобів на пішоходів, які перетинали проїзну частину по наземному нерегульованому пішохідному переходу, необхідно також давати експертну оцінку технічному облаштуванню даних переходів, технікоексплуатаційним показникам їх облаштування, або вказувати слідчому про виявлення фактів неналежного облаштування наземних нерегульованих пішохідних переходів і який вплив це має на встановлення всіх обставин, що могли стати причиною виникнення цього виду ДТП. 


\title{
ЭКСПЕРТНОЕ ИССЛЕДОВАНИЕ ДОРОЖНО-ТРАНСПОРТНЫХ ПРОИСШЕСТВИЙ, ОТНОСЯЩИХСЯ К НАЕЗДАМ НА ПЕШЕХОДОВ ПРИ НЕНАДЛЕЖАЩЕМ ТЕХНИЧЕСКОМ ОБУСТРОЙСТВЕ ПЕШЕХОДНОГО ПЕРЕХОДА
}

\author{
Ольхов В. С., Степко В. А., Панасенко А. Н.
}

Рассмотрены вопросы, возникающие у экспертов при проведении судебных автотехнических экспертиз (экспертных исследований) при наезде на пешеходов, которые пересекали проезжую часть по наземному нерегулируемому пешеходному переходу.

Ключевые слова: дорожно-транспортное происшествие, наземный нерегулируемый пешеходный переход, пешеход, наезд на пешехода.

\section{EXPERT RESEARCH OF TRAFFIC ACCIDENTS RELATED TO COLLISIONS ON PEDESTRIANS IN THE CASE OF INAPPROPRIATE TECHNICAL CONSTRUCTION OF PEDESTRIAN CROSSING}

\author{
Olhov V. S., Stepko V. O., Panasenko O. N.
}

Today, in the expert practice during technical analysis of vehicle drivers' actions who committed the collision on the pedestrian on the ground unregulated pedestrian crossing which is not properly marked, there is no uniform approach to the technical evaluation of drivers' actions in case of traffic accident commitment. This problem is not resolved properly both in the theoretical and practical aspects. This creates conditions for different approaches to the technical evaluation of vehicle driver actions in the analysis of traffic accident circumstances. Generally, in reference and normative literature on the theory and practice of forensic auto-technical and road technical examinations there are no works that would be dealt with the problems of this kind since it requires to carry out complex road technical and auto-technical researches with the aim to establish compliance of equipment, location, operating status of technical means and engineering constructions in the zones of unregulated pedestrian crossings action. In conducting researches of collisions on pedestrians who passed a driveway on the ground unregulated pedestrian crossing, it's also necessary to give expert evaluation to the technical construction of these crossings, technical and operational indicators or point out on the revealed facts of their improper construction to the investigator and what impact it has on the determination of all circumstances that could give rise to this type of traffic accident. Experts of Kharkiv RIFE make the first attempt to create a unified approach to the technical evaluation of drivers' actions in the case of traffic accident associated with collisions on pedestrians when ground unregulated pedestrian crossing is improperly technically constructed, namely the technique is developed, in which the algorithm of carrying out such researches is proposed.

Keywords: road traffic accident, ground unregulated pedestrian crossing, pedestrian, collision on the pedestrian. 